\title{
Replacement of fish meal with a matrix of organic plant proteins in organic trout (Oncorhynchus mykiss) feed, and the effects on nutrient utilization and fish performance
}

\author{
Ivar Lund ${ }^{\mathrm{a}, *}$, Johanne Dalsgaard ${ }^{\mathrm{a}}$, Hanne Tolderlund Rasmussen ${ }^{\mathrm{b}}$, Jørgen Holm ${ }^{\mathrm{c}}$, Alfred Jokumsen ${ }^{\mathrm{a}}$ \\ a Technical University of Denmark, DTU Aqua, Section for Aquaculture, North Sea Research Centre, DK-9850 Hirtshals, Denmark \\ b Centre for Process Innovation, Technological Institute, Kolding, Denmark \\ c BioMar Ltd., Brande, Denmark
}

\section{A R T I C L E I N F O}

\section{Article history:}

Received 7 June 2011

Received in revised form 19 September 2011

Accepted 22 September 2011

Available online 1 October 2011

\section{Keywords:}

Organic

Rainbow trout

Plant protein

Nutrient utilization

$\mathrm{N}$

$\mathrm{P}$

\begin{abstract}
A B S T R A C T
This study examined the effects on nutrient utilization and fish performance when replacing 16,31 , and $47 \%$ of fish meal protein (corresponding to replacing 15, 29 and 44\%, respectively, of total dietary protein) with a fixed matrix of organic pea, horsebean and rapeseed plant protein concentrates (PPC) in a ratio of 1.07:1.00:0.66. Four iso-energetic and iso-nitrogenous diets were produced to include $0,136,274$ or $410 \mathrm{~g} \mathrm{~kg}^{-1}$ of the organic PPC matrix, respectively. The organic protein ingredients were chosen based on their high protein content, and the matrix was established to mirror the amino acid composition of fish meal. The plant ingredients were dried, dehulled, grinded and air classified in accordance with the European Union Commission Regulation on organic aquaculture production, increasing the protein concentrations up to $577 \mathrm{~g} \mathrm{~kg}^{-1}$ dry matter. Two experiments were carried out using juvenile rainbow trout (Oncorhynchus mykiss): 1) a digestibility study to examine the apparent digestibility of protein, lipid, nitrogen-free extract (NFE), total phosphorus and phytate-phosphorus, followed by a water sampling period to determine the output of nitrogen and phosphorus and enabling the setup of nitrogen and phosphorus mass-balances; and 2) a 57 day growth study including 3 growth periods each of 19 days and using pit-tagged fish. Substituting fish meal with organic PPC significantly increased the apparent digestibility coefficient (ADC) of protein and lipid $(\mathrm{P}<0.008)$ at the highest PPC inclusion level, while there was a significant $(\mathrm{P}<0.044)$ decrease in the ADC of NFE with increasing PPC inclusion level. The apparent digestibility coefficient of phytate-phosphorus was significantly lower $(\mathrm{P}<0.005)$ at the highest PPC inclusion level compared to the fish meal control diet. The mass-balances revealed a significant increase in the excretion of ammonium-nitrogen $\left(\mathrm{NH}_{4} \mathrm{~N}, \mathrm{P}<0.017\right)$ at the two highest PPC inclusion levels and a decrease in phosphorus $(\mathrm{P}<0.009)$ excretion at the highest organic PPC inclusion level. There was no overall effect on the specific growth rates (SGRs) or feed conversion ratios (FCRs). The study thus demonstrated that it is possible to replace fish meal by $47 \%$ organic PPC without compromising rainbow trout performance. However, the results also indicated that it will be difficult to replace much more than this as long as supplementation with synthetic amino acids and exogenous phytase is not allowed in organic feed.
\end{abstract}

(c) 2011 Elsevier B.V. All rights reserved.

\section{Introduction}

The principles of organic aquaculture encourage the development of fish feeds containing fish meal from sustainable fisheries only to avoid depleting global fish stocks (EU, 2007, 2009). In combination with an increasing demand for organic trout (Bergleiter et al., 2009), this stresses the need for alternative, organic feed ingredients.

Only a couple of previous studies have examined the effects of replacing fish meal with organic protein ingredients on fish performance,

\footnotetext{
* Corresponding author. Tel.: + 45 35883205; fax: + 4535883260.

E-mail address: il[a]aqua.dtu.dk (I. Lund).
}

and none of the studies have looked at rainbow trout. Lunger et al. (2006, 2007) found that up to $40 \%$ fish meal protein may be replaced by organically certifiable protein sources in feed for juvenile cobia (Rachycentron canadum) without negatively affecting performance.

In contrast to organic feed, much of the current research in conventional (i.e. non-organic) feed for salmonids examines the substitution of fish meal by vegetable proteins (e.g., Gatlin et al., 2007; Glencross et al., 2010; Øverland et al., 2009), and studies have shown that it is possible to substitute a significant part of fish meal with plant protein concentrates without compromising fish growth when supplementing the diet with indispensable amino acids (e.g., Kaushik et al., 1995; Rodehutscord et al., 1995). Such results cannot be directly applied to organic aquaculture where the organic code of 
practice implies certain limits to the feed (reviewed by Mente et al., 2011). Following the European Union's regulation No. 834/2007 on organic production and labeling of organic products (EU, 2007), it is not allowed to add synthetic amino acids to the feed or to use chemically solvent related purification methods of the plant ingredients. It is therefore necessary, when formulating an organic diet, to blend a selection of different vegetable protein sources with high protein contents and complementary amino acid profiles, since optimization of the amino acid profile of organic feed must be based on the protein sources alone. An optimized amino acid profile can only be obtained by combining a number of plant protein ingredients as no single agricultural crop can provide a suitable amino acid composition (Gaylord et al., 2010; Kaushik, 1990).

Proteins in high quality fish meal are palatable, highly digestible ( $90 \%)$ and anti-nutritional factors (ANFs) are more or less nonexisting (Gatlin et al., 2007; Gaylord et al., 2010). Substituting fish meal with organic plant ingredients thus faces further challenges, as plant-based ingredients often contain a variety of indigestible carbohydrates some of which may also have anti-nutrient effects, along with a number of non-carbohydrate anti-nutrients (Francis et al., 2001; Jezierny et al., 2010; Krogdahl et al., 2010). The latter includes phytate (myo-inositol hexaphosphate), which is the main phosphorus storage form in plants (Cheryan, 1980; Ravindran et al., 1994). Phytate-phosphorus is highly unavailable to carnivorous fish, which lack the enzyme phytase needed for catalyzing the hydrolysis of phytate and rendering the phosphorus available for uptake (Ellestad et al., 2002; Pallauf and Rimbach, 1997; Sajjadi and Carter, 2004). As processing any feed materials with the aid of chemically synthesized solvents or supplementation with exogenous phytase is not allowed in feed for organic trout, the availability of dietary phosphorus may become a limiting factor for organic fish.

Another consequence of the restrictions against chemically synthesized solvents is that it is difficult to reduce the content of indigestible carbohydrates in organic plant feed ingredients, which have been shown to reduce the nutritional value of conventional feed in many fish species (e.g., Glencross, 2009; Krogdahl et al., 2010; Refstie et al., 1999).

The objective of the present study was to examine the effects on nutrient utilization and fish performance when gradually substituting fish meal by a matrix of organic pea (Pisum sativum) protein concentrate (PC), organic horsebean (Vicia faba) protein concentrate (HC), and organic rapeseed (Brassica napus) protein concentrate (RS). The three plant protein sources were chosen based on their, for plant protein ingredients, relatively high protein content, and the matrix was established to mirror the amino acid composition of high quality fish meal.

\section{Materials and methods}

\subsection{Protein sources and diet composition}

Danish produced organic pea beans, organic horse beans and organic rapeseed were obtained from Toft Foods A/S, DLF-TRIFOLIUM A/S and Lehnsgaard Aakirkeby respectively, while a high quality, low temperature (LT) fish meal was obtained from FF Skagen, Denmark. The plant protein sources were dried, dehulled, grinded, and air classified at the Centre of Process Innovation, Technological Institute, Denmark, to reduce the content of anti-nutrients and obtain crude protein concentrations of 512,518 and $331 \mathrm{~g} \mathrm{~kg}^{-1}$ in the pea, horse bean, and rapeseed meal, respectively.

Four iso-energetic and iso-nitrogenous experimental diets (A, B, C, D) were formulated by BioMar Ltd based on proximate analyses of the four protein feed ingredients (Table 1). Diet A served as a control diet containing fish meal as the primary protein source (i.e., fish meal constituting $94 \%$ of total dietary protein), while 16,31 and $47 \%$ of the fish meal protein in diet A (corresponding to 15, 29 and 44\%, respectively, of total dietary protein) were replaced by an organic protein matrix consisting of PC, HB and RS in the ratio 1.07:1.00:0.66 (Table 1 ) in diet B, C, and $D$, respectively. The maximum inclusion level of the plant protein concentrate (PPC) matrix (i.e., $44 \%$ of total dietary protein) was determined by the protein content and amino acid composition of the PPC matrix. Wheat was used as filler to balance the diets.

The diets were produced by the Danish Technological Institute using a twin-screw Werner \& Pfleider 37 extruder and fabricated as $3.0 \mathrm{~mm}$ pellets. They were stored at $2{ }^{\circ} \mathrm{C}$ throughout the study.

The crude protein and lipid content of the four experimental diets was quite similar, ranging between $44.2-46.0 \%$ for protein and 29.0 $30.8 \%$ for lipid (Table 1 ). The total phosphorus (TP) content of the four diets was also very similar (1.43-1.47\%), while the phytate-P content increased with increasing plant protein supplementation that is, increasing from $8.5 \%$ of TP in diet A to $21.5 \%$ of TP in diet D. High TP levels in the PPC diets were due to unexpectedly high levels of TP in the analyzed PPC batches deviating from common literature values.

There was generally little variation between the four diets in the content of essential amino acids except for methionine and threonine whose content decreased with increasing PPC inclusion (Table 1).

\subsection{Experimental design and procedures}

Two experiments were carried out: 1) A digestibility trial followed by a water sampling period to determine the apparent digestibility coefficients (ADCs) of dietary nutrients as well as the composition and magnitude of dissolved nitrogen $(\mathrm{N})$ and phosphorus $(\mathrm{P})$ waste produced, which enabled the construction of complete $\mathrm{N}$ and $\mathrm{P}$ budgets; and 2) a growth study to determine the specific growth rates (SGRs) and feed conversion ratios (FCRs) of the four diets. The experiments were carried out at the North Sea Research Centre, Denmark, using juvenile rainbow trout (Oncorhynchus mykiss) obtained from Binderup Fish Farm, Denmark.

\subsubsection{Digestibility and mass-balance study (experiment 1)}

This experiment lasted 24 feeding days and was designed as a fully random, single factorial experiment with three replicate tanks for each of the four experimental diets (i.e., $n=3$ experimental units per diet, 12 tanks in all). Fish with an initial mean weight of $67.0 \pm$ $7.3 \mathrm{~g}$ were randomly distributed at a stocking density of 19 fish tank ${ }^{-1}$ among twelve, $189 \mathrm{~L}$, cylindrical-conical, flow-through, thermoplastic tanks in a modified Guelph setup as previously described (Dalsgaard and Pedersen, 2011). All fecal particles were collected in separated sedimentation columns submerged in ice-water to prevent biological breakdown between samplings. The tanks were supplied with $10^{\circ} \mathrm{C}$ tap water at a flow rate of $40 \mathrm{~L} \mathrm{~h}^{-1}$. A $15 \mathrm{~h} \mathrm{light:9} \mathrm{h} \mathrm{dark} \mathrm{diurnal} \mathrm{photo-}$ period was maintained throughout the trial, and oxygen saturation levels were kept between 70 and $100 \%$ at all times. The fish were acclimatized to the experimental conditions and to the diets for 7 days prior to the commencement of the experiment. They were individually weighed at the start of the experiment (day 0 ), and a pooled sample of 9 fish was collected from each dietary treatment group serving as initial carcass samples, while all remaining fish in each tank were sacrificed by the end of the experiment, serving as final carcass samples.

The fish were fed $1.5 \%$ of their biomass $\mathrm{d}^{-1}$ for 12 days (calculated based on an expected FCR). The daily ration was divided into two equal portions which were fed at 10:00 and 14:00 h, respectively. Feed waste was registered and counted throughout the trial. All feces from the sedimentation columns were collected daily prior to feeding at 10:00 h, and samples from each three consecutive days were pooled (i.e., yielding four fecal sampling periods) and stored at $-20^{\circ} \mathrm{C}$ until chemical analysis was carried out. Feces from the first sampling period served as back-up samples, while feces from the second and third sampling periods were analyzed for protein, 
Table 1

Ingredient (\%) and analyzed nutrient composition (\%, mean \pm S.D., $\mathrm{n}=2)$ of the experimental diets.

\begin{tabular}{|c|c|c|c|c|}
\hline Diet $^{\mathrm{a}}$ & $A$ & B & $C$ & $\mathrm{D}$ \\
\hline \multicolumn{5}{|l|}{ Ingredients (\%) } \\
\hline Fish meal ${ }^{\mathrm{b}}$ & 58.9 & 51.0 & 43.1 & 35.2 \\
\hline Wheat ${ }^{\mathrm{C}}$ & 20.2 & 14.1 & 8.0 & 2.0 \\
\hline Organic pea protein concentrate ${ }^{\mathrm{d}}$ & 0.0 & 5.3 & 10.7 & 16.0 \\
\hline Organic horse bean protein concentrate $\mathrm{e}^{\mathrm{e}}$ & 0.0 & 5.0 & 10.0 & 15.0 \\
\hline Organic rapeseed protein concentrate $\mathrm{f}^{\mathrm{f}}$ & 0.0 & 3.3 & 6.7 & 10.0 \\
\hline Fish oil ${ }^{\mathrm{b}}$ & 22.3 & 22.4 & 22.5 & 22.6 \\
\hline Vitamins and minerals ${ }^{g}$ & 0.8 & 0.8 & 0.8 & 0.8 \\
\hline \multicolumn{5}{|l|}{ Proximate composition $(\%)^{h}$} \\
\hline Dry matter & $96.6 \pm 0.0$ & $95.9 \pm 0.0$ & $97.9 \pm 0.0$ & $97.8 \pm 0.0$ \\
\hline Crude protein & $44.2 \pm 0.1$ & $44.6 \pm 0.2$ & $45.4 \pm 0.4$ & $46.0 \pm 0.0$ \\
\hline Crude lipid & $30.8 \pm 0.2$ & $29.0 \pm 0.6$ & $30.5 \pm 0.0$ & $29.9 \pm 0.0$ \\
\hline NFE (incl. crude fiber) & $12.9 \pm 0.1$ & $13.7 \pm 0.4$ & $13.6 \pm 0.3$ & $13.7 \pm 0.0$ \\
\hline Ash & $8.8 \pm 0.0$ & $8.6 \pm 0.0$ & $8.4 \pm 0.1$ & $8.2 \pm 0.0$ \\
\hline Total P & $1.47 \pm 0.0$ & $1.45 \pm 0.0$ & $1.46 \pm 0.0$ & $1.43 \pm 0.0$ \\
\hline Phytate-P & 0.13 & 0.18 & 0.25 & 0.31 \\
\hline Tryptophan & $(0.47) 0.48$ & $(0.48) 0.48$ & (0.49) 0.47 & (0.49) 0.45 \\
\hline Isoleucine & (1.80) 1.70 & (1.81) 1.69 & (1.82) 1.77 & (1.83) 1.76 \\
\hline Leucine & (3.37) 3.31 & (3.34) 3.29 & (3.32) 3.38 & (3.30) 3.25 \\
\hline Histidine & $(0.86) 0.95$ & $(0.91) 0.99$ & (0.93) 1.04 & (0.95) 1.04 \\
\hline Lysine & (3.39) 3.25 & (3.31) 3.24 & 3.30 & (3.15) 3.19 \\
\hline Methionine & (1.17) 1.20 & (1.07) 1.09 & (0.97) 1.01 & 0.90 \\
\hline Phenylalanine & (1.71) 1.71 & (1.74) 1.74 & (1.77) 1.83 & (1.80) 1.82 \\
\hline Threonine & (1.73) 1.92 & (1.71) 1.86 & (1.70) 1.88 & (1.68) 1.78 \\
\hline Valine & (2.24) 2.16 & (2.22) 2.11 & (2.20) 2.16 & (2.18) 2.11 \\
\hline Arginine & $(2.42) 2.89$ & (2.55) 2.97 & (2.68) 3.18 & (2.81) 3.17 \\
\hline
\end{tabular}

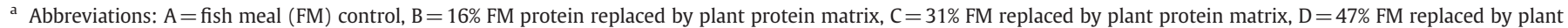
protein matrix.

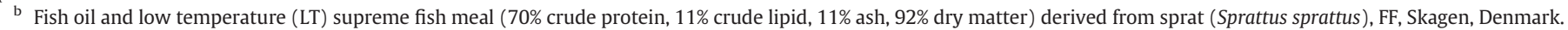

c BioMar, Brande, Denmark.

d Organic peas (Pisum sativum), Toft Food A/S, Denmark: 51.2\% crude protein, 3.0\% crude lipid, 28.8\% NFE, 7.1\% ash, 1.1\% total phosphorus, 90.1\% dry matter.

e Organic horse beans (Vicia faba), DLF-Trifolium A/S, Denmark: 51.8\% crude protein, $2.4 \%$ crude lipid, 29.0\% NFE, 6.6\% ash, 1.0\% total phosphorus, 89.8\% dry matter.

${ }^{f}$ Organic rapeseeds (Brassica napus), Lehnsgaard, Aakirkeby, Denmark: 33.1\% crude protein, 14.8\% crude lipid, 35.7\% NFE, 7.3\% ash, 1.6\% total phosphorus, 90.9\% dry matter.

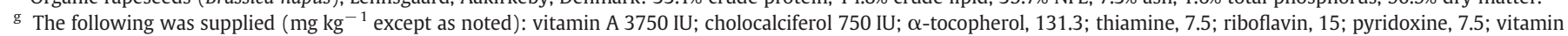
$\mathrm{B}_{12}, 0.002$; vitamin $\mathrm{K}_{3}, 7.5$; zinc, 75; iodine, 0.9; copper, 3.75; manganese, 22.5; cobalt, 0.75; selenium, 0.19.

${ }_{\mathrm{h}}$ Amino acid values in parenthesis were calculated using the feed formulation software Allix from A-systems SA (Versailles, France).

lipid, dry matter (DM), ash and total phosphorus. Feces from the fourth sampling period were analyzed for phytate-P.

The fish were individually weighed at the end of the digestibility trial (day 13), and returned to the tanks where they were fed a fixed daily ration for 12 days corresponding to $1.5 \%$ of the biomass measured at the end of the digestibility trial. This was done to ensure that the dissolved waste produced ( $\mathrm{N}$ and $\mathrm{P}$ ) was generated from a well defined and constant amount of feed. After the first 5 days of this period, influent water was turned off for $24 \mathrm{~h}$ (and air diffusion turned on) and the waste produced was measured as the delta increase derived from water samples collected just prior to feeding at 10:00 and $24 \mathrm{~h}$ later, respectively. The procedure was repeated after 72 h (i.e., 3 days) to obtain replicate measures for each tank.

\subsubsection{Growth study (experiment 2)}

The second experiment included 57 feeding days and was designed as a fully random, single factorial experiment with two replicate tanks for each experimental diet (i.e., $\mathrm{n}=2$ experimental units per diet, 8 tanks in all). It was carried out in a recirculation freshwater system consisting of $1.18 \mathrm{~m} \times 1.18 \mathrm{~m}$ fiber glass tanks with an average water depth of $0.55 \mathrm{~m}$, a mechanical filter (Hydrotech), a submerged biofilter, and a trickling filter (both BioBlok 150-200, EXPO-NET, Hjørring, Denmark). A $14 \mathrm{~h}$ light:10 h dark regime was maintained throughout the experiment.

Juvenile fish were randomly distributed among eight tanks and tagged individually by injecting a unique passive integrated transponder (Pit tag, Jojo Automasjon A/S, Stavanger, Norway) into the right side muscle below the dorsal fin after anesthetizing the fish with tricaine methanesulfonate (MS 222). The fish were acclimatized to the system and experimental diets for 7 days. The density in each tank was adjusted to $8 \mathrm{~kg} \mathrm{~m}^{-3}$ at the start of the experiment, and the fish with an initial mean weight of $65.7 \pm 13.3 \mathrm{~g}$ were subsequently fed $1.3 \%$ of their biomass $\mathrm{d}^{-1}$ (calculated based on an expected FCR) for 57 days. The feeding period was divided into 3 growth periods of 19 days, each followed by weighing of all individuals and adjusting of the ration. Daily feed waste was collected using swivel unit separators mounted to the tanks and counted throughout the experiment. Dissolved oxygen levels were kept above $70 \%$ saturation $\left(>7.4 \mathrm{mg} \mathrm{L}^{-1}\right)$ at all times during the experiment, and the water temperature was maintained at $15.9 \pm 0.3^{\circ} \mathrm{C}$. Ammonium-nitrogen $\left(\mathrm{NH}_{4} \mathrm{~N}\right)$ was kept below $0.5 \mathrm{mg} \mathrm{NH}_{4} \mathrm{~N} \mathrm{~L}^{-1}$, nitrite-nitrogen $\left(\mathrm{NO}_{2} \mathrm{~N}\right)$ below $1 \mathrm{mg} \mathrm{NO}_{2} \mathrm{NL}^{-1}$, nitrate-nitrogen $\left(\mathrm{NO}_{3} \mathrm{~N}\right)$ ranged between 0 and $25 \mathrm{mg} \mathrm{NO}_{3} \mathrm{NL}^{-1}$, and $\mathrm{pH}$ ranged between 7.8 and 7.9 .

\subsection{Chemical analysis}

Samples of the plant protein concentrates and the formulated diets were homogenized using a Krups Speedy Pro homogenizer and analyzed for dry matter and ash (NMKL, 1991), crude protein (ISO, 2005; crude protein = Kjeldahl $\mathrm{N} \times 6.25$ ), crude lipid (Bligh and Dyer, 1959) and total phosphorus (ISO, 1998). The phytate-P content of the diets was determined as the difference in TP (determined by ICP-AES (ICP VISTA MPX, Varian)) before and after separation and extraction of phytates on an anion exchange column (Harland and Oberleas, 1986; Plaami and Kumpulainen, 1991). The essential amino acid composition of the diets (Hardy, 2002) was determined by a commercial laboratory (Eurofins Steins Laboratorium A/S, Denmark). 
Fecal samples from sampling periods 2 and 3 in experiment 1 were thawed, homogenized using an Ultra Turrax, and analyzed for $\mathrm{DM}$, ash, protein, lipid and TP as described for the diets. Fecal samples from the fourth sampling period in experiment 1 were lyophilized prior to phytate-P analysis as described for the diets.

Water samples were analyzed for total nitrogen (ISO, 1986, 1997), total ammonia nitrogen (TAN; DS, 1975), and TP (ISO, 2004).

Carcass analyses of initial and final fish samples were carried out by removing the digestive system of the fish to avoid contamination from any undigested feed. The pooled carcasses were autoclaved for $1 \mathrm{~h}\left(120^{\circ} \mathrm{C}\right)$, homogenized using a Braun hand processor, and analyzed for protein, lipid, DM, ash and TP as described for the diets.

\subsection{Calculations}

Nitrogen-free extract (NFE) was calculated as DM less the sum of crude protein, crude lipid, and ash. The apparent digestibility coefficients (ADCs, \%) of dietary nutrients and minerals, as obtained from the direct and total collection method of measuring in experiment 1, were calculated as (Jobling, 1994):

$\mathrm{ADC}_{i}=100 *\left(\mathrm{C}_{i}-\mathrm{F}_{i}\right) / \mathrm{C}_{i}$,

where $i$ corresponds to a dietary macronutrient or mineral (i.e., protein, lipid, NFE, ash, TP or phytate-P), C is the consumed amount of $i$, and $\mathrm{F}$ is the fecal loss of $i$.

Complete $\mathrm{N}$ and $\mathrm{P}$ mass-balances were set up based on the total duration of the first experiment (24 days), and following the approach by Cho et al. (1994) modified to measure dissolved waste directly:

$\mathrm{X}$ consumed $=\mathrm{X}$ retained $+\mathrm{SWX}+\mathrm{DWX}$,

where X refers to $\mathrm{N}$ or TP, SWX refers to solid waste $\mathrm{N}$ or TP, and DWX refers to dissolved waste $\mathrm{N}$ or TP. Retained $\mathrm{N}$ or TP was calculated based on whole body chemical composition analyses of fish sampled at the start and at the end of the experiment as (Jobling, 2001):

$\mathrm{X}$ retained $=\left(\mathrm{X}\right.$ in biomass $\mathrm{end}_{\mathrm{e}}-\mathrm{X}$ in biomass $\left.\mathrm{start}_{\mathrm{s}}\right) / \mathrm{X}$ consumed.

The solid waste output of $\mathrm{N}$ or TP was calculated as:

$\mathrm{SWX}=\left(1-\mathrm{ADC}_{\mathrm{X}}\right) * \mathrm{X}$ consumed.

The dissolved output of $\mathrm{N}$ or TP (including suspended solids) was measured directly in the water and for inclusion in the mass-balances calculated as:

$\mathrm{DWX}=\left(\mathrm{DWX}_{\mathrm{t} 24}-\mathrm{DWX} \mathrm{X}_{\mathrm{t} 0}\right) * \mathrm{~L} / \mathrm{X}$ consumed,

where $\mathrm{DWX}_{\mathrm{t} 0}$ and $\mathrm{DWX}_{\mathrm{t} 24}$ refer to $\mathrm{N}$ or TP concentrations in water samples obtained just prior to feeding and $24 \mathrm{~h}$ later, respectively, in a tank with closed valves, and $\mathrm{L}=$ volume of the tank in liter. Excretion of TAN was derived similarly to DWX.

The feed conversion ratio (FCR, $\mathrm{g} \mathrm{g}^{-1}$ ) was calculated based on the biomass weight gain and the registered feed intake (feed administered - feed waste) as (Guillaume, 2001):

$\mathrm{FCR}=$ feed intake $(\mathrm{g}) /$ weight gain $(\mathrm{g})$.

The specific growth rate (SGR, \% $\mathrm{d}^{-1}$ ) was calculated based on the overall biomass gain in the tanks as well as on the gain of tagged individuals in each growth period in the second experiment according to (Hopkins, 1992):

$\mathrm{SGR}=100 *\left(\ln \mathrm{W}_{\mathrm{t}}-\ln \mathrm{W}_{0}\right) / \Delta \mathrm{t}$

where $\mathrm{W}_{\mathrm{t}}$ refers to average weight at day $\mathrm{t}, \mathrm{W}_{0}$ refers to the average weight at day $t_{0}$, and $\Delta t$ is the number of days. In addition, the thermal growth coefficient (TGC) was calculated as follows according to (Jobling, 2003):

$\mathrm{TGC}=1000 *\left[\left(\mathrm{~W}_{\mathrm{t}}\right)^{1 / 3}-\left(\mathrm{W}_{0}\right)^{1 / 3} *(\mathrm{~T}-\mathrm{t})\right]$

where $\mathrm{T}$ is the temperature in ${ }^{\circ} \mathrm{C}$, and $\mathrm{t}$ is the time in days.

\subsection{Statistical analysis}

Experimental data were subjected to single factor analysis of variance (ANOVA) using Sigma Stat 3.5 to detect statistically significant differences between treatment means. Levenes test was used to check for homogeneity of variance within the treatment groups, and Holm Sidak all pairwise multiple comparison of means test was applied for testing significance of mean differences between the four treatment groups where applicable. The significance level was set at $\mathrm{P}<0.05$, and values are throughout the text expressed as the mean \pm standard deviation.

\section{Results}

\subsection{Digestibility (experiment 1)}

The fish accepted all diets well, and little feed waste was generally observed during the experiment $(1-3.5 \%$ of the administered feed diet $^{-1}$ ). The apparent digestibility of crude protein ranged from 90.6 to $92.3 \%$, and it was significantly higher for diet D than for diet $\mathrm{B}(\mathrm{P}<0.011)$ (Table 2). The apparent digestibility of lipid increased with organic PPC supplementation, and it was significantly higher for diet $\mathrm{D}$ than for diet $\mathrm{A}(\mathrm{P}<0.037)$. The apparent digestibility of NFE decreased almost linearly with organic PPC supplementation and there were significant differences between all four treatment groups $(\mathrm{P}<0.048)$. The apparent digestibility of TP appeared to decrease with organic PPC supplementation, but the decrease was not significant. The apparent digestibility of phytate-P was significantly lower for $\operatorname{diet} C$ and $D$ than for $\operatorname{diet} A(P<0.040)$. There were no differences in the apparent digestibility of ash or DM between the treatment groups. The fish in the digestibility study grew from $67.0 \pm$ $7.7 \mathrm{~g}$ to $113.2 \pm 24.7 \mathrm{~g}$ during the 24 feeding days, and there were no significant differences in SGR, TGC or FCR between dietary treatment groups (Table 3).

Table 2

Apparent nutrient digestibility coefficients (ADC, \%) (mean \pm S.D., $n=6)$ of the experimental diets ${ }^{\mathrm{a}}$.

\begin{tabular}{lllll}
\hline Diet $^{\mathrm{b}}$ & $\mathrm{A}$ & $\mathrm{B}$ & $\mathrm{C}$ & $\mathrm{D}$ \\
\hline Protein & $91.9 \pm 0.7^{\mathrm{ab}}$ & $90.6 \pm 1.3^{\mathrm{a}}$ & $91.3 \pm 0.5^{\mathrm{ab}}$ & $92.3 \pm 0.6^{\mathrm{b}}$ \\
Lipid & $89.1 \pm 2.2^{\mathrm{a}}$ & $89.8 \pm 2.3^{\mathrm{ab}}$ & $90.0 \pm 1.4^{\mathrm{ab}}$ & $92.0 \pm 0.6^{\mathrm{b}}$ \\
NFE & $55.8 \pm 3.7^{\mathrm{d}}$ & $45.3 \pm 5.7^{\mathrm{c}}$ & $34.7 \pm 3.1^{\mathrm{b}}$ & $28.3 \pm 5.8^{\mathrm{a}}$ \\
Ash & $49.0 \pm 4.9$ & $49.9 \pm 3.3$ & $50.1 \pm 1.4$ & $52.5 \pm 1.8$ \\
DM & $85.4 \pm 1.4$ & $83.9 \pm 1.7$ & $82.9 \pm 0.6$ & $82.9 \pm 1.2$ \\
TP & $66.1 \pm 3.9$ & $64.8 \pm 1.3$ & $64.2 \pm 2.0$ & $62.0 \pm 2.3$ \\
Phytate-P & $53.0 \pm 9.9^{\mathrm{b}}$ & $29.0 \pm 15.8^{\mathrm{ab}}$ & $12.9 \pm 8.8^{\mathrm{a}}$ & $19.9 \pm 4.3^{\mathrm{a}}$ \\
Digestible energy $(\mathrm{MJ} / \mathrm{kg})^{\mathrm{c}}$ & 21.7 & 20.9 & 21.5 & 21.6 \\
DP/DE (g/MJ) & 18.7 & 19.3 & 19.3 & 19.7 \\
\hline
\end{tabular}

${ }^{a}$ Values not sharing a common superscript letter within a row are significantly different $(P<0.05)$.

${ }^{b}$ Abbreviations: $\mathrm{A}=$ fish meal (FM) control, $\mathrm{B}=16 \% \mathrm{FM}$ protein replaced by plant protein matrix, $C=31 \%$ FM replaced by plant protein matrix, $D=47 \%$ FM replaced by plant protein matrix.

c Digestible energy (DE) of the diets. Calculated by multiplying dietary nutrient compositions (Table 1) by nutrient energy contents (c.f. Jobling, 1994: 23.7, 39.6, $17.2 \mathrm{MJ} / \mathrm{kg}$ for protein, lipid and NFE, respectively) and apparent nutrient digestibility coefficients (Table 2).

${ }^{d}$ Digestible protein/digestible energy. 
Table 3

Feed intake (FI, kg), feed conversion ratios (FCR, feed intake (g)/weight gain $(\mathrm{g})$ ), specific growth rates (SGR, \% $\mathrm{d}^{-1}$ ), and thermal growth coefficient (TGC) of rainbow trout obtained during a 24 days digestibility study (mean \pm S.D., $n=3$; experiment 1 ), or a 57 days growth study (mean \pm S.D., $n=2$; experiment 2 ) when feeding the experimental diets.

\begin{tabular}{lllll}
\hline Diet $^{\mathrm{a}}$ & $\mathrm{A}$ & $\mathrm{B}$ & $\mathrm{C}$ & $\mathrm{D}$ \\
\hline Exp. 1 & & & & \\
FI & $0.52 \pm 0.10$ & $0.53 \pm 0.09$ & $0.57 \pm 0.02$ & $0.59 \pm 0.01$ \\
FCR & $0.63 \pm 0.04$ & $0.67 \pm 0.06$ & $0.62 \pm 0.01$ & $0.62 \pm 0.01$ \\
SGR & $2.10 \pm 0.33$ & $1.98 \pm 0.28$ & $2.33 \pm 0.06$ & $2.29 \pm 0.03$ \\
TGC & $0.83 \pm 0.14$ & $0.77 \pm 0.13$ & $0.92 \pm 0.02$ & $0.91 \pm 0.02$ \\
& & & & \\
Exp. 2 & & & & \\
FI & $7.76 \pm 0.76$ & $7.81 \pm 0.15$ & $7.52 \pm 0.65$ & $7.82 \pm 0.34$ \\
FCR & $0.75 \pm 0.01$ & $0.78 \pm 0.03$ & $0.73 \pm 0.03$ & $0.78 \pm 0.01$ \\
SGR & $1.82 \pm 0.03$ & $1.77 \pm 0.06$ & $1.85 \pm 0.08$ & $1.77 \pm 0.02$ \\
TGC & $0.80 \pm 0.02$ & $0.77 \pm 0.03$ & $0.81 \pm 0.06$ & $0.78 \pm 0.02$ \\
\hline
\end{tabular}

a Abbreviations: $\mathrm{A}=$ fish meal $(\mathrm{FM})$ control, $\mathrm{B}=16 \% \mathrm{FM}$ protein replaced by plant protein matrix, $C=31 \% \mathrm{FM}$ replaced by plant protein matrix, $\mathrm{D}=47 \% \mathrm{FM}$ replaced by plant protein matrix.

b SGR calculated based on biomass values rather than on individually tagged fish.

\subsection{Mass-balances and waste excretion (experiment 1)}

Complete nitrogen and phosphorus mass-balances for each of the four dietary treatment groups are presented in Figs. 1 and 2, respectively. The mass-balances have been standardized to a recovery rate of $100 \%$ to ease the interpretation of the figures, and residual $\mathrm{N}$ and $\mathrm{TP}$ values are stated in figure footnotes. There were no significant differences in retained $\mathrm{N}$ (50.9-53.2\%, i.e. corresponding to $36.1-38.6 \mathrm{~g} \mathrm{~N} \mathrm{~kg}$ feed $\left.^{-1}\right)$, solid waste $\mathrm{N}\left(6.9-8.6 \%\right.$, i.e. 5.1-6.2 $\mathrm{g} \mathrm{N} \mathrm{kg} \mathrm{feed}^{-1}$ ) or dissolved waste $\mathrm{N}$ (38.1-40.9\%, i.e. $27.7-29.8 \mathrm{~g} \mathrm{~N} \mathrm{~kg} \mathrm{feed}^{-1}$ ) between dietary treatment groups (Fig. 1). However, the output of TAN increased significantly $(P<0.01)$ with organic PPC supplementation, from 63 to $68 \%$ of dissolved waste $\mathrm{N}$ in diet $\mathrm{A}$ and $\mathrm{D}$, respectively. The residual $\mathrm{N}$ varied from -5 to $-10 \%$, indicating that more $\mathrm{N}$ was recovered than consumed by the fish with no obvious trends related to the dietary treatment groups. Residual N reflected general measurement uncertainties,

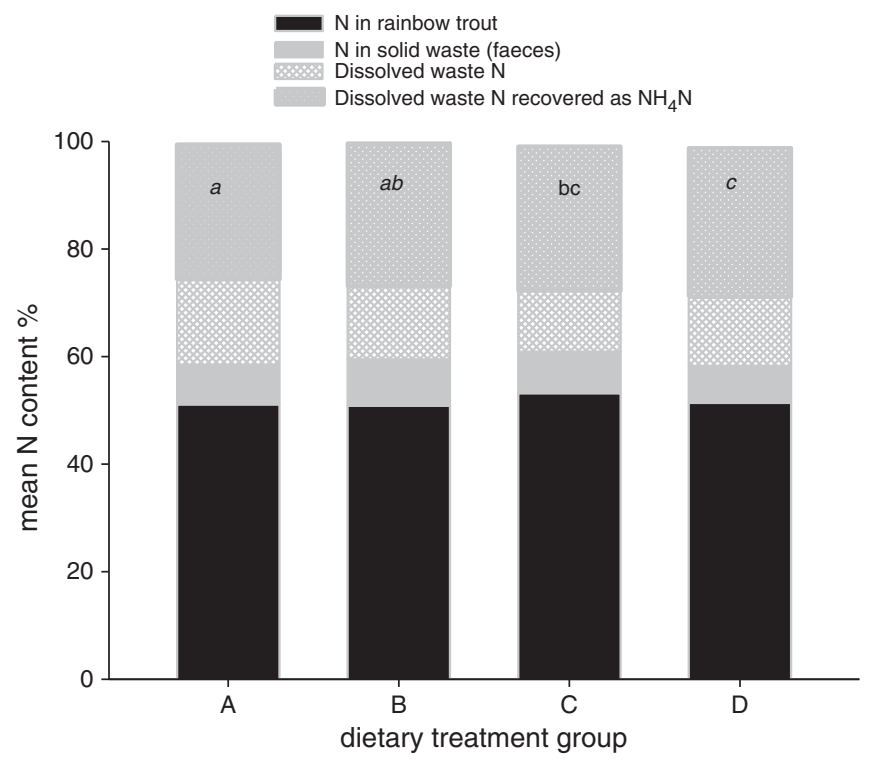

Fig. 1. Mean nitrogen $(N)$ mass-balances $(n=3)$ for juvenile rainbow trout fed four experimental diets: A, B, C, or D, in which $0,16,31$ or $47 \%$ fish meal protein, respectively, were replaced by a matrix of plant protein concentrate. Data are adjusted to $100 \%$ of the nitrogen feed intake. Residual nitrogen (\%): $-7.6 \pm 2.1,-4.7 \pm 4.3,-9.5 \pm 2.2$ and $-10.4 \pm 4.8$ for diet A, B, C and D, respectively. Different lower case letters between dietary treatment groups indicate that the amount of dissolved waste $\mathrm{N}$ recovered as $\mathrm{NH}_{4} \mathrm{~N}$ was significantly different $(\mathrm{P}<0.05)$.

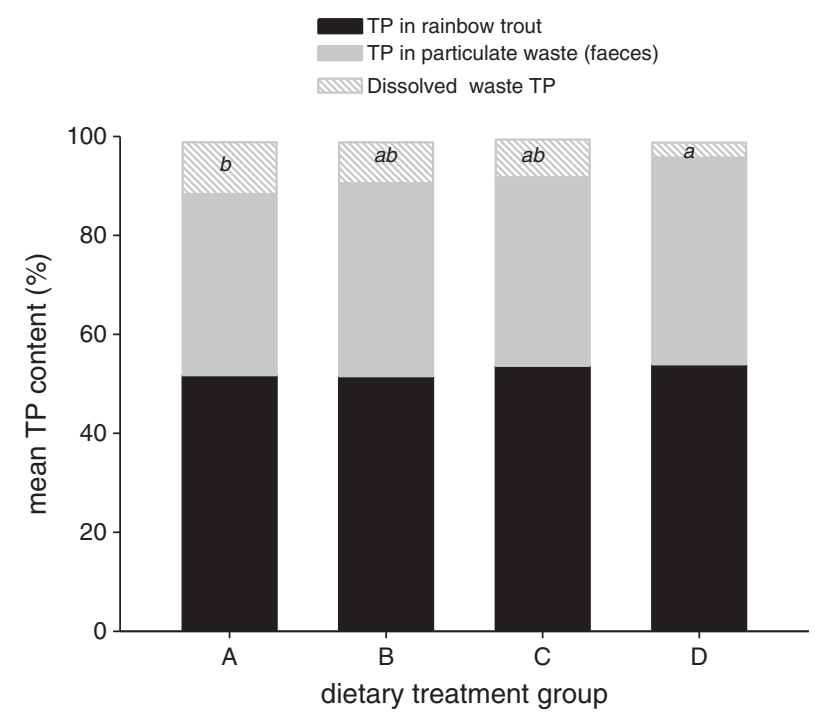

Fig. 2. Mean total phosphorus (TP) mass-balances $(n=3)$ for juvenile rainbow trout fed four experimental diets: A, B, C, or D, in which $0,16,31$ or $47 \%$ fish meal protein, respectively, was replaced by a matrix of plant protein concentrate. Data are adjusted to $100 \%$ of the total phosphorus feed intake. Residual TP (\%): $10.3 \pm 3.9^{\mathrm{ab}}, 14.8 \pm 1.6^{\mathrm{b}}$, $7.9 \pm 0.9^{\mathrm{a}}$ and $11.0 \pm 2.5^{\mathrm{ab}}$, respectively, different superscript letters indicating that the residual values were significantly different between the dietary treatment groups $(\mathrm{P}<0.05)$. Different lower case letters between dietary treatment groups in the figure indicate that the amount of dissolved waste TP was significantly different $(\mathrm{P}<0.05)$.

time variation in sampling, and the fact that different analytical methods had to be applied for measuring retained and solid vs. dissolved waste $\mathrm{N}$.

The phosphorus mass-balances (Fig. 2) showed no differences in retained TP (51.5-53.9\%, i.e. 7.4-7.8 $\mathrm{g} \mathrm{TP} \mathrm{kg} \mathrm{feed}^{-1}$ ) or solid TP waste $\left(37.0-41.3 \%\right.$, i.e. $\left.5.4-6.0 \mathrm{~g} \mathrm{TP} \mathrm{kg} \mathrm{feed}{ }^{-1}\right)$, while the output of dissolved waste TP decreased significantly $(P=0.018)$ with PPC supplementation from $10.5 \%$ in the diet A to $3.0 \%$ in diet $\mathrm{D}$ corresponding to a decrease from 1.5 to $0.4 \mathrm{~g} \mathrm{TP} \mathrm{kg} \mathrm{feed}^{-1}$. The residual TP varied from 8 to $15 \%$ with no obvious trends related to the dietary treatment groups, meaning that less TP was recovered than consumed by the fish. As for $\mathrm{N}$, residual TP reflected general measurement uncertainties, time variation in sampling, and the fact that different analytical methods had to be applied for measuring retained and solid versus dissolved waste TP.

\subsection{Growth and feed conversion ratio (experiment 2)}

The fish generally accepted all diets, and the sum of feed waste was less than $1 \%$ of the administered feed per diet. The fish grew from an average initial weight of $65.7 \pm 13.3 \mathrm{~g}$ to an average final weight for all dietary treatment groups of $182.0 \pm 48.1 \mathrm{~g}$ during the 57 feeding days of the second experiment. There were no significant differences in overall SGR, TGC or FCR between the dietary treatment groups during the 57 feeding days (Table 3). Twelve fish died during the study, and the deaths were not associated with any specific dietary treatment group.

\section{Discussion}

Organic production of herbivorous and omnivorous aquaculture species such as tilapia and catfish appears to be relatively straight forward as organic feedstuff may largely cover their nutritional needs and therefore readily replace conventional feedstuff (e.g., Craig and Mclean, 2005; Li et al., 2006). Formulating organic diets for carnivorous species is a much larger challenge due to their high protein/ essential amino acid requirement and the ban against adding synthetic amino acids in organic feed (EU, 2007). The present study 
showed that an organic PPC matrix consisting of pea, horsebean and rapeseed in a ratio composed to optimize the dietary amino acid composition may replace 47 of fish meal protein (corresponding to $44 \%$ of total dietary protein) without negatively affecting fish performance. The growth rate, thermal growth coefficient, and FCR were thus similar for all dietary treatment groups both when calculated based on the total feeding period of 57 days in the second experiment, and when calculated based on the 24 feeding days in the digestibility trial. These results are similar to findings for cobia ( $R$. canadum), where Lunger et al. (2007) showed that $40 \%$ of fish meal protein may be replaced by different organically certifiable, individually supplemented protein sources (yeast-derived protein, soybean meal, soybean isolate, or hemp seed meal) without negatively affecting performance. Lunger et al. (2006) previously showed that a higher inclusion level of yeast-derived protein (50-100\%) had detrimental effects on juvenile cobia performance as well as on various biological indices (muscle ratio, visceral somatic index, hepatosomatic index). Similarly, an equal blend of four alternative, organic protein sources replacing $92 \%$ of fish meal in a diet for juvenile cobia was shown to lead to poor performance and 53\% lower survival rate compared to fish fed a fish meal control diet, and no fish survived $100 \%$ replacement of fish meal (Lunger et al., 2007). These results were attributed to a lack of essential amino acids. Indices of incipient amino acid imbalance were also observed in the present study. Hence, whereas there were no overall differences in the $\mathrm{N}$ mass-balances between the four treatment groups, there was a significant increase in the excretion of $\mathrm{NH}_{4} \mathrm{~N}$ at the highest organic PPC inclusion level. Ammoniumnitrogen is the main nitrogen waste product of protein catabolism in fish (Kaushik and Cowey, 1991), and an increase in the excretion of $\mathrm{NH}_{4} \mathrm{~N}$ indicates that the fish were catabolizing a relatively larger share of the digested protein compared to the other treatment groups at the expense of channeling it into growth. The dietary content of methionine and threonine decreased with organic PPC supplementation, and the concentration of methionine was below that generally recommended for rainbow trout (Hardy, 2002). This substantiates the hypothesis that fish performance was not improved at the highest PPC inclusion level despite a higher apparent protein digestibility due to a shortage of methionine. A potential amino acid imbalance and the consequences on protein catabolism may also explain why the increase in apparent lipid digestibility at the highest PPC inclusion level did not result in improved growth. The "surplus" energy obtained from the improved apparent lipid digestibility may thus have been deposited in the fish or potentially spent on covering increased energy expenditures associated with increased $\mathrm{NH}_{4} \mathrm{~N}$ excretion (Wilkie, 2002).

Anti-nutrients in plant feed crops constitute a bigger problem in organic than in conventional fish farming due to the restrictions against the use of chemically synthesized, solvent-extraction processes (EU, 2007). Dehulling and extrusion do not remove all anti-nutrients (Francis et al., 2001; Krogdahl et al., 2010). Saponins and non-starch polysaccharides (NSPs) may be able to withstand thermal processing during formulation and extruding, whereas protease inhibitors, phytic acid, lectins, tannins and glycosinolates are more heat labile (Francis et al., 2001; Krogdahl et al., 2010). The problem with anti-nutrients is further amplified by the fact that the quantity of many anti-nutrients is batch/strain related and influenced by growing conditions (e.g., Gatlin et al., 2007; Tripathi and Mishra, 2007).

Anti-nutritional effects of for example soluble NSPs in soybean are hypothesized to involve binding or trapping and subsequent excretion of particularly bile salts, leading to reduced nutrient absorption in NSP rich diets (Gatlin et al., 2007). The effects may be combined with possible gradual pathological changes in the intestinal microbiota or mucosal morphology (Drew et al., 2007) leading to a lower nutrient uptake. Intestinal enteritis has been observed in Atlantic salmon (Salmo salar) exposed for a few weeks to a diet with $10 \%$ soybean meal (Bæverfjord and Krogdahl, 1996), and anti-nutrients in plant feed stuffs other than soybean may cause intestinal inflammable responses in salmonids (Krogdahl et al., 2010).

The composition and levels of anti-nutrients apart from phytate-P were not investigated in the organic ingredients examined in the present study, but the more or less linear decrease in the apparent NFE digestibility with organic PPC supplementation indicates that the diets contained increasing concentrations of indigestible carbohydrates. The decrease in the apparent NFE digestibility did not appear to affect growth, which was probably due to the generally low NFE content in the diets (13-14\%).

Aside from the problems of anti-nutrients discussed above, restrictions on organic plant protein processing methods further limit the inclusion level of organic PPCs due to the low protein content that can be obtained in the ingredients. Hence, following dehulling, grinding and air classification, the protein concentrations of the organic PPC in the present study were equal to or below $577 \mathrm{~g} \mathrm{~kg}^{-1}$ $\mathrm{DM}$, which is well below the desired $700 \mathrm{~g} \mathrm{~kg}^{-1} \mathrm{DM}$ typical for fish meal (Gaylord et al., 2010). This fact limits the inclusion level of organic PPC taking into account that rainbow trout diets should preferably include at least 40\% protein (Hardy, 2002; Kim et al., 1991; NRC, 1981).

Phytate-phosphorus is another ANF of concern when using organic PPC, as this form of phosphorus is generally of limited availability to fish (Cao et al., 2008; Dalsgaard et al., 2009; Ellestad et al., 2002; Pallauf and Rimbach, 1997; Rodehutscord et al., 2000; Sajjadi and Carter, 2004). In the present study, the phytate-P concentration increased with increasing organic PPC supplementation, constituting $9 \%$ of TP in diet A and 22\% of TP in diet D. Consistent with this, there appeared to be a trend towards decreasing apparent TP digestibility (Table 2) accompanied by a decreasing output of dissolved waste TP (Fig. 3). The decreasing trend in apparent TP digestibility was most likely due to the lower apparent phytate-P digestibility in diet $\mathrm{C}$ and $\mathrm{D}$ compared to diet $\mathrm{A}$. The relatively high apparent phytate-P digestibility in diet A and B should probably be held up against the low phytate-P concentration in the diets and consequently very low and varying replicate phytate-P levels recovered in the feces. Alternatively, the high apparent phytate-P digestibility may reflect a limited capacity of rainbow trout to hydrolyze phytic acid and render the phosphorus available for uptake, or the presence of low concentrations of endogenous plant phytase in the PPC matrix.

From an environmental point of view, a decrease in dissolved waste TP may seem appealing, as this waste fraction is difficult to remove and may lead to eutrophication in watersheds receiving the

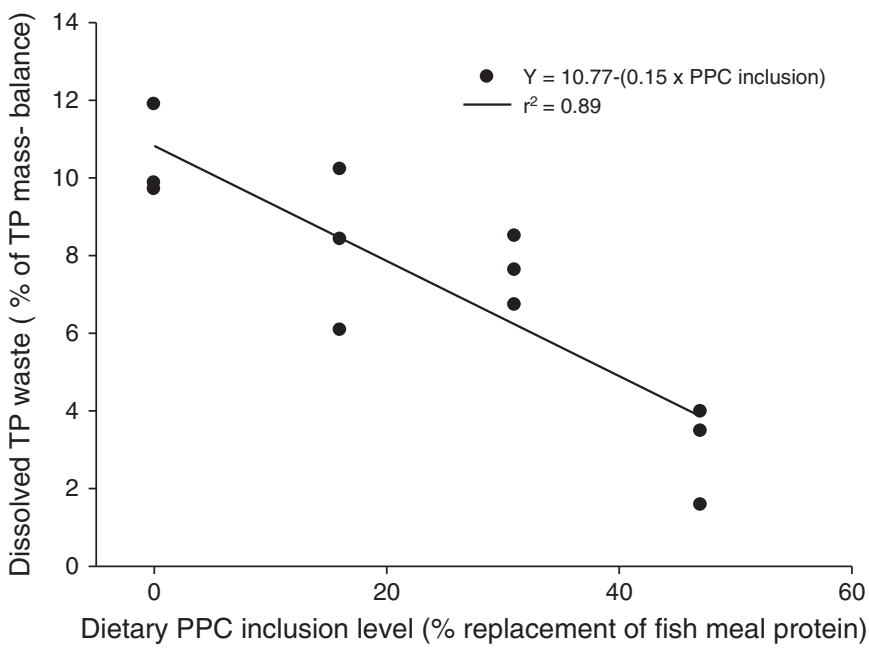

Fig. 3. Dissolved total phosphorus (TP) waste (\%, based on the TP mass-balances in Fig. 2) as a function of replacing $0,16,31$, or $47 \%$ of fish meal protein in diet A, B, C, and $\mathrm{D}$, respectively, with a matrix of plant protein concentrates (PPC) (corresponding to replacing $0,15,29$, or $44 \%$, respectively of total dietary protein). 
aquaculture effluent (Dalsgaard and Pedersen, 2011). From a fish point of view, less $\mathrm{P}$ will be available for growth as the dietary phytate-P concentration increases, and the fish may eventually become P-limited. The urinary P output, included in the dissolved waste TP fraction in the present study, may be used as an indicator of $P$ deficiency in rainbow trout as the concentration decreases to an absolute minimum when the fish become P-limited (Dalsgaard and Pedersen, 2011; Sugiura et al., 2000a). Due to an unexpectedly high TP and low phytate-P content in the PPC diets, the fish in the present study did not appear to be P-limited even at the highest PPC inclusion level. The availability of TP in diet D, obtained with a FCR of 0.62 and standardized to a FCR of 1 in order to compare with other studies (i.e.: $14.6 \mathrm{~g} \mathrm{TP} \mathrm{kg}^{-1}$ dry feed $* \mathrm{TP}$ apparent digestibility $\left.{ }_{62} * \mathrm{FCR}_{0.62} / \mathrm{FCR}_{1}\right)$, was $5.56 \mathrm{~g} \mathrm{TP} \mathrm{kg}^{-1}$ dry feed. This value is similar to the breakpoint value of similar size fish found by Dalsgaard and Pedersen (2011) above which the dissolved $P$ concentration starts increasing. In comparison, Sugiura et al. (2000b) found breakpoint values of 5.85 and $4.42 \mathrm{~g}$ available $\mathrm{P} \mathrm{kg}^{-1}$ dry feed for 200 and $400 \mathrm{~g}$ trout, respectively.

Based on the phosphorus mass balance results, it can be derived that there in theory would have been no discharge of dissolved waste TP at a PPC inclusion level of $72 \%$, equal to a pea:horsebean: rapeseed inclusion ratio of approximately 28:26:17 (Fig. 3). Such a high inclusion level would almost certainly not be able to fulfill the phosphorus requirement of the fish. There thus appears to be a minimum metabolic requirement and concomitant excretion of phosphorus below the dietary breakpoint value (Dalsgaard and Pedersen, 2011), suggesting that fish fed available dietary phosphorus concentrations below the breakpoint value will be forced to utilize intrinsic phosphorous reserves. Furthermore, the amino acid requirement of the fish would almost certainly not be satisfied at this high inclusion level as observed by Lunger et al. $(2006,2007)$ when replacing more than $40 \%$ fish meal protein with organic protein in feed for cobia.

To realize a PPC inclusion level higher than in the present study would in practice require that organic processing techniques are improved to optimize the protein/amino acid content in relevant plant protein concentrates and reduce the level of anti-nutrients. The inclusion of PPCs was only examined at a fixed dietary protein level. However, the DP/DE ratios (digestible protein/digestible energy; 19.319.7, Table 2) of the PPC diets were only slightly above the optimal $\mathrm{DP} / \mathrm{DE}$ value for juvenile rainbow trout given an optimum dietary amino acid pattern (Green and Hardy, 2008). It will therefore be difficult to reduce the overall dietary protein level in an organic diet much more than in the present study, without negatively affecting fish performance and $\mathrm{N}$ waste excretion.

In addition to the protein/amino acid content, plant crop batches may vary significantly in their phytate/TP content, influenced further by the particular strain/variety, soil type, type of fertilization used, growing season, etc. (Manangi and Coon, 2006; Tagoe et al., 2010). Preceding TP and phytate-P analysis of plant protein ingredients are therefore required to optimize the dietary inclusion level with respect to available phosphorus, and to ensure a minimum phosphorus load discharge in water effluents. All of this makes it an even bigger challenge to establish the maximum dietary level of organic plant protein concentrates that may be included in feed for organic carnivorous fish.

\section{Conclusion}

The present study showed that it is possible to replace $47 \%$ of fish meal protein (corresponding to $44 \%$ of total dietary protein) with a matrix of organic plant protein concentrates consisting of pea:horsebean: rapeseed in a ratio of 1.07:1.00:0.66 without affecting fish performance. However, the excretion of $\mathrm{NH}_{4} \mathrm{~N}$ increased with increasing PPC substitution, suggesting that the fish were close to experiencing an imbalance in the dietary, indispensable amino acid composition. Furthermore, the recovery of dissolved TP decreased with increasing PPC substitution, indicating that the availability of dietary phosphorus was decreasing towards an absolute minimal dietary requirement at the highest inclusion level. As long as amino acid supplementation is not allowed in organic feed formulation for carnivorous species it will be difficult to replace much larger fractions of fish meal protein by organic plant protein concentrates in feed for organic trout than demonstrated in the present study.

\section{Acknowledgments}

The present research work was granted as a part of the research project: "The linkage between sustainable production and superior products (ORAQUA)" under the research program: Research in Organic Food and Farming (DARCOF III, 2005-2010) by the International Centre for Research in Organic Food Systems (ICROFS) and funded by the Ministry of Food, Agriculture and Fisheries.

The authors are grateful to the technicians Erik Poulsen and Ulla Sproegel, DTU Aqua for technical assistance as well as Head of Aquaculture Section, Per Bovbjerg Pedersen, DTU Aqua for critical review of the manuscript.

\section{References}

Bæverfjord, G., Krogdahl, Å., 1996. Development and regression of soybean meal induced enterititis in Atlantic salmon distal intestine. A comparison with the intestines of fasted fish. Journal of Fish Diseases 19, 375-387.

Bergleiter, S., Berner, N., Censkowsky, U., Julià-Camprodon, G., 2009. Organic aquaculture 2009: production and markets. In: Naturland e.V., Organic Services GmbH (Eds.), Organic Aquaculture 2009: Production and markets, p. 120. Gräfelfing/Munich.

Bligh, E.G., Dyer, W.J., 1959. A rapid method of total lipid extraction and purification. Canadian Journal of Biochemistry and Physiology 37, 265-272.

Cao, L., Yang, Y., Wang, W.M., Yakupitiyage, A., Yuan, D.R., Diana, J.S., 2008. Effects of pretreatment with microbial phytase on phosphorous utilization and growth performance of Nile tilapia (Oreochromis niloticus). Aquaculture Nutrition 14, 99-109.

Cheryan, M., 1980. Phytic acid interactions in food systems. Critical Reviews in Food Science and Nutrition 13, 297-335.

Cho, C.Y., Hynes, J.D., Wood, K.R., Yoshida, H.K., 1994. Development of high-nutrient-dense, low-pollution diets and prediction of aquaculture wastes using biological approaches. Aquaculture 124, 293-305

Craig, S.R., Mclean, E., 2005. The organic aquaculture movement: a role for $\mathrm{NuPro}^{\mathrm{TM}}$ as an alternative protein source. In: Jacques, K., Lyons, P. (Eds.), Nutritional Biotechnology in the Food and Feed Industry. Nottingham University Press, UK, pp. 285-293.

Dalsgaard, J., Pedersen, P.B., 2011. Solid and suspended/dissolved waste (N, P, O) from rainbow trout (Oncorhynchus mykiss). Aquaculture 313, 92-99.

Dalsgaard, J., Ekmann, K.S., Pedersen, P.B., Verlhac, V., 2009. Effect of supplemented fungal phytase on performance and phosphorus availability by phosphorusdepleted juvenile rainbow trout (Oncorhynchus mykiss), and on the magnitude and composition of phosphorus waste output. Aquaculture 286, 105-112.

Drew, M.D., Borgeson, T.L., Thiessen, D.L., 2007. A review of processing of feed ingredients to enhance diet digestibility in finfish. Animal Feed Science and Technology 138, 118-136.

DS (Danish Standards), 1975. Water analysis. Determination of ammonia-nitrogen, DS 224:1975. Dansk Standardiseringsråd, Denmark. 6 pp.

Ellestad, L.E., Angel, R., Soares Jr., J.H., 2002. Intestinal phytase II: a comparison of activity and in vivo phytate hydrolysis in three teleost species with differing digestive strategies. Fish Physiology and Biochemistry 26, 259-273.

EU, 2007. Council Regulation (EC) No. 834/2007 of 28 June 2007 on organic production and labelling of organic products and repealing Regulation (EEC) No. 2092/91. Official Journal of the European Union, Legislation 189 (50), 1-23.

EU, 2009. Commission Regulation (EC) No. 710/2009 of 5 August 2009 amending Regulation (EC) No. 889/2008 laying down detailed rules for the implementation of Council Regulation (EC) No. 834/2007, as regards laying down detailed rules on organic aquaculture animal and seaweed production. Official Journal of the European Union, Legislation 204 (52), 15-34

Francis, G., Makkar, H.B.S., Becker, K., 2001. Antinutritional factors present in plantderived alternate fish feed ingredients and their effects in fish. Aquaculture 199, 197-227.

Gatlin, D.M., Barrows, F.T., Brown, P., Dabrowski, K., Gaylord, T.G., Hardy, R.W., Herman, E., Hu, G., Krogdahl, Å., Nelson, R., Overturf, K., Rust, M., Sealey, W., Skonberg, D., J Souza, E., Stone, D., Wilson, R., Wurtele, E., 2007. Expanding the utilization of sustainable plant products in aquafeeds: a review. Aquaculture Research 38, 551-579.

Gaylord, T.G., Barrows, F.T., Rawles, S.D., 2010. Apparent amino acid availability from feedstuffs in extruded diets for rainbow trout Oncorhynchus mykiss. Aquaculture Nutrition 16, 400-406.

Glencross, B., 2009. The influence of soluble and insoluble lupin non-starch polysaccharides on the digestibility of diets fed to rainbow trout (Oncorhynchus mykiss). Aquaculture 294, 256-261. 
Glencross, B., Sweetingham, M., Hawkins, W., 2010. A digestibility assessment of pearl lupin (Lupinus mutabilis) meals and protein concentrates when fed to rainbow trout (Oncorhynchus mykiss). Aquaculture 303, 59-64.

Green, J.A., Hardy, R.W., 2008. The effects of dietary protein:energy ratio and amino acid pattern on nitrogen utilization and excretion of rainbow trout Oncorhynchus mykiss (Walbaum). Journal of Fish Biology 73, 663-682.

Guillaume, J., 2001. Terminology and methodology. In: Guillaume, J., Kaushik, S., Bergot, P., Métailler, R. (Eds.), Nutrition and Feeding of Fish and Crustaceans. Springer-Praxis, Chichester, UK, pp. 9-16.

Hardy, R.W., 2002. Rainbow trout, Oncorhynchus mykiss. In: Webster, C.D., Lim, C. (Eds.), Nutrient Requirements and Feeding of Finfish for Aquaculture. CABI Publishing, Oxon, UK, pp. 184-202.

Harland, B.F., Oberleas, D., 1986. Anion exchange method for determination of phytate in foods: collaborative study. Journal of the Association of Official Agricultural Chemists 69, 667-670.

Hopkins, K.D., 1992. Reporting fish growth: a review of the basics. Journal of the World Aquaculture Society 23, 173-179.

ISO, 1986. Water quality - determination of nitrate. Part 1: 2.6-Dimethylphenol Spectrometric Method, ISO 7890-1:1986. International Organization for Standardization, Geneva. 15 pp.

ISO, 1997. Water Quality - Determination of Nitrogen. Part 1: Method Using Oxidative Digestion with Peroxodisulfate, ISO 11905-1:1997. International Organization for Standardization, Geneva. $13 \mathrm{pp}$

ISO, 1998. Animal Feeding Stuffs - Determination of Phosphorus Content Spectrometric Method, ISO 6491:1998. International Organisation for Standardization, Genewa. $16 \mathrm{pp}$.

ISO, 2004. Water Quality - Determination of Phosphorus-Ammonium Molybdate Spectrometric Method, ISO 6878:2004. International Organisation for Standardization, Geneva. 21 pp.

ISO, 2005. Animal Feeding Stuffs - Determination of Nitrogen Content and Calculation of Crude Protein Content - Part 2: Block Digestion/Steam Distillation Method, ISO 5983-2:2005. International Organisation for Standardization, Geneva. 14 pp.

Jezierny, D., Mosenthin, R., Bauer, E., 2010. The use of grain legumes as a protein source in pig nutrition: a review. Animal Feed Science and Technology 157, 111-128.

Jobling, M., 1994. Fish Bioenergetics, first ed. Chapman \& Hall, London.

Jobling, M., 2001. Feed composition and analysis. In: Houlihan, D.F., Boujard, T., Jobling, M. (Eds.), Food Intake in Fish. Blackwell Science Ltd., Oxford, pp. 1-24.

Jobling, M., 2003. The thermal growth coefficient (TGC) modelof fish growth: a cautionary note. Aquaculture Research 34, 581-584.

Kaushik, S.J., 1990. Use of alternative protein sources for the intensive rearing of carnivorous fishes. In: Flos, R., Tort, L., Torres, P. (Eds.), Mediterranean Aquaculture. Ellis Horwood, Chicester, UK, pp. 125-138.

Kaushik, S.J., Cowey, C.B., 1991. Dietary factors affecting nitrogen excretion by fish. In: Cowey, C.B., Cho, C.Y. (Eds.), Nutritional Strategies and Aquaculture Waste. Guelph, Ontario, pp. 3-20.

Kaushik, S.J., Cravedi, J.P., Lalles, J.P., Sumpter, J., Fauconneau, B., Laroche, M., 1995. Partial or total replacement of fish meal by soybean protein on growth, protein utilization, potential estrogenic or antigenic effects, cholesterolemia and flesh quality in rainbow trout, Oncorhynchus mykiss. Aquaculture 133, 257-274.

Kim, K.-I., Kayes, T.B., Amundson, C.H., 1991. Purified diet development and re-evaluation of the dietary protein requirement of fingerling rainbow trout (Oncorhynchus mykiss). Aquaculture 96, 57-67.

Krogdahl, Å., Penn, M., Thorsen, J., Refstie, S., Bakke, A.M., 2010. Important antinutrients in plant feedstuffs for aquaculture: an update on recent findings regarding responses in salmonids. Aquaculture Research 41, 333-344.

Li, M.H.H., Robinson, E.H., Mischke, C.C., Torrans, E.L., Bosworth, B.G., 2006. Effects of organic fertilization and organic diets on production of channel catfish in earthen ponds. North American Journal Of Aquaculture 68, 53-62.
Lunger, A.N., Craig, S.R., McLean, E., 2006. Replacement of fish meal in cobia (Rachycentron canadum) diets using an organically certified protein. Aquaculture 257, 393-399.

Lunger, A.N., McLean, E., Craig, S.R., 2007. The effects of organic protein supplementation upon growth, feed conversion and texture quality parameters of juvenile cobia (Rachycentron canadum). Aquaculture 264, 342-352.

Manangi, M.K., Coon, C.N., 2006. Evaluation of phytase enzyme with chicken fed basa diets containing different soy bean meal samples. Journal of Applied Poultry Research $15,292-306$.

Mente, E., Karalazos, V., Karapanagiotidis, I.T., Pita, C., 2011. Review article. Nutrition in organic aquaculture: an inquiry and a discourse. Aquaculture Nutrition. doi:10.1111/ j.1365-2095.2010.00846.x.

NMKL (Nordic Committee on Food Analysis), 1991. Moisture and ash. Gravimetric Determination in Meat and Meat products, NMKL 23. Nordic Committee on Food Analysis, Oslo, Norway. 4 pp.

NRC (National Research Council), 1981. Nutrient requirements of coldwater fishes. Nutrient Requirements of Domestic Animals Series. National Academy of Sciences, Washington, DC. 83 pp.

Øverland, M., Sorensen, M., Storebakken, T., Penn, M., Krogdahl, A., Skrede, A., 2009. Pea protein concentrate substituting fish meal or soybean meal in diets for Atlantic salmon (Salmo salar) - effect on growth performance, nutrient digestibility, carcass composition, gut health, and physical feed quality. Aquaculture 288, 305-311.

Pallauf, J., Rimbach, G., 1997. Nutritional significance of phytic acid and phytase. Archives of Animal Nutrition (Archiv fur Tierernahrung) 50, 301.

Plaami, S., Kumpulainen, J., 1991. Determination of phytic acid in cereals using ICP-AES to determine phosphorus. Journal of the Association of Official Agricultural Chemists 74, 32-36.

Ravindran, V., Ravindran, G., Sivalogan, S., 1994. Total and phytate phosphorus contents of various foods and feedstuffs of plant origin. Food Chemistry 50, 133-136.

Refstie, S., Svihus, B., Shearer, K.D., Storebakken, T., 1999. Nutrient digestibility in Atlantic salmon and broiler chickens related to viscosity and non-starch polysaccharide content in different soyabean products. Animal Feed Science and Technology 79, 331-345.

Rodehutscord, M., Mandel, S., Pack, M., Jacobs, S., Pfeffer, E., 1995. Free amino acids can replace protein-bound amino acids in test diets for studies in rainbow trout (Oncorhynchus mykiss). Journal of Nutrition 125, 956-963.

Rodehutscord, M., Gregus, Z., Pfeffer, E., 2000. Effect of phosphorus intake on faecal and non-faecal phosphorus excretion in rainbow trout (Oncorhynchus mykiss) and the consequences for comparative phosphorus availability studies. Aquaculture 188 383-398.

Sajjadi, M., Carter, C.G., 2004. Effect of phytic acid and phytase on feed intake, growth, digestibility and trypsin activity in Atlantic salmon (Salmo salar, L.). Aquaculture Nutrition 10, 135-142.

Sugiura, S.H., Dong, F.M., Hardy, R.W., 2000a. Primary responses of rainbow trout to dietary phosphorus concentration. Aquaculture Nutrition 6, 235-245.

Sugiura, S.H., Dong, F.M., Hardy, R.W., 2000b. A new approach to estimating the minimum dietary requirement of phosphorus for large rainbow trout based on nonfecal excretions of phosphorus and nitrogen. Journal of Nutrition 130 , $865-872$.

Tagoe, S.O., Horiuchi, T., Matsui, T., 2010. Effect of carbonized chicken manure on the growth, nodulation, yield nitrogen and phosphorus contents of four grain legumes. Journal of Plant Nutrition 33 (5), 684-700.

Tripathi, M.K., Mishra, A.S., 2007. Glucosinolates in animal nutrition. A review. Anima Feed Science and Technology 132, 1-27.

Wilkie, M.P., 2002. Ammonia excretion and urea handling by fish gills: present understanding and future research challenges. Journal of Experimental Zoology 293, 284-301. 